\title{
Burkitt lymphoma and Ewing sarcoma in a child with Williams syndrome
}

Nelli Vanhapiha, $\mathrm{MB}^{1}$, Sakari Knuutila, MD, $\mathrm{PhD}^{2}$, Kim Vettenranta,MD, $\mathrm{PhD}^{3}$, Olli Lohi, MD, PhD ${ }^{1}$

${ }^{1}$ Tampere Center for Child Health Research, University of Tampere Medical School and Tampere University Hospital, Tampere, Finland.

${ }^{2}$ Department of Pathology, University of Helsinki, Helsinki, Finland.

${ }^{3}$ Hospital for Children and Adolescents, University of Helsinki and Helsinki University Hospital, Helsinki, Finland.

Nelli Vanhapiha

Syventävien opintojen kirjallinen työ

Tampereen yliopisto

Lääketieteen yksikkö

Toukokuu 2014 
Tampereen yliopisto

Lääketieteen yksikkö

Lastentautien tutkimuskeskus

Nelli Vanhapiha: Burkitt lymphoma and Ewing sarcoma in a child with Williams syndrome

Kirjallinen työ, $5 \mathrm{~s}$.

Ohjaaja: dosentti Olli Lohi

Toukokuu 2014

Avainsanat: kromosomitranslokaatio, kehityshäiriö, syöpäriski

\section{Tiivistelmä}

Tapausseloste Williamsin syndroomaa sairastavasta lapsesta, jolla diagnosoitiin ensin Burkittin lymfooma ja myöhemmin Ewingin sarkooma

Williamsin syndrooma on verrattain harvinainen kehityshäiriö (prevalenssi 1/10 000), jonka saa aikaan kromosomaalinen mikrodeleetio toisessa kromosomin 7 kopiossa alueella 11q23. Noin 28 geenin kattava deleetio saa aikaan tyypillisen fenotyypin, johon kuuluu sydämen epämuodostuma (tavallisesti supravalvulaarinen aorttastenoosi), tyypilliset kasvonpiirteet sekä älyllinen kehitysvammaisuus, joka on vaihtelevan tasoista. Oireyhtymälle tyypillisiin neurokognitiivisiin erityispiirteisiin kuuluvat kielen kehityksen viivästyminen, puutteet näönvaraisessa tulkinnassa sekä ylenpalttinen empaattisuus.

Williamsin syndrooman ei ole osoitettu lisäävän riskiä sairastua syöpään. Kuitenkin useat julkaisut ovat osoittaneet, että kromosomin 7 mutaatiot ovat tavallisia useissa erityyppisissä kasvaimissa. Erityisesti hematologisissa maligniteeteissa ja pediatrisissa sarkoomissa kromosomitranslokaatiot ovat yleisiä, mutta mekanismi, joka saa aikaan translokaation syntymisen, ymmärretään vain osittain.

Kuvaamme ainutlaatuisen potilaan, jolla on varhaislapsuudessa diagnosoitu kehityshäiriö, Williamsin syndrooma. Potilas sairasti myöhemmin sekä Burkittin lymfooman että Ewingin sarkooman. Molempien syöpien osalta potilas on nyt remissiossa. Edeltävästi kirjallisuudessa on raportoitu ainoastaan 14 tapausta, joissa Williamsin syndroomaa sairastavalla on diagnosoitu jokin maligniteetti, eikä ainuttakaan, jossa sairastettuja syöpiä olisi useampi. 
Sisällysluettelo

Abstract

Introduction

1

Case report

1

Figure 1.

2

Discussion

3

Table 1.

4

Conflict of interest

5

References

5 


\begin{abstract}
Williams syndrome (WS) is a relatively rare multisystem neurodevelopmental disorder caused by a hemizygous deletion of contiguous genes on chromosome 7q11.23. Although WS does not predispose carriers to cancers, alterations of chromosome 7 are common in several human neoplasms. We report here a patient with WS and two different cancers, Burkitt lymphoma and Ewing sarcoma. Array-CGH analysis of the patient blood revealed a constitutive 1.4 million base pair deletion at 7q11.23, compatible with WS diagnosis.
\end{abstract}

Keywords: Burkitt lymphoma; chromosomal translocation; Ewing sarcoma; Williams syndrome

\title{
Introduction
}

Williams syndrome (WS, also known as Williams-Beuren syndrome) is a genetic disorder caused by a deletion of 26-28 genes at chromosome $7 \mathrm{q} 11.23$. The prevalence of the disorder is approximately 1 in 10000 [1]. The patients with WS have various clinical characteristics including facial dysmorphia (prominent ear lobes, flat nasal bridge, epicanthal folds, wide mouth with full cheeks, etc.), cardiovascular abnormalities (particularly supravalvular aortic stenosis), short stature and mental retardation of a varying degree. The distinctive neurocognitive profile of WS consists of a delay in early language skills, deficits in visual-motor integration, overfriendliness and a strong sense of empathy[1]. Here we report a WS patient who encountered two different malignant tumors, a Burkitt lymphoma and Ewing sarcoma.

\section{Case report}

The patient was diagnosed with WS at the age of two years based on typical clinical characteristics including facial dysmorphia, a heart murmur due to supravalvular stenosis, growth deficiency and delay in neurological development. Diagnosis was further confirmed by fluorescence in situ hybridization (FISH) of blood nucleated cells showing deletion at chromosome 7q11.23.

At the age of nine years the patient suffered from acute abdominal pain and was suspected of appendicitis. Ultrasound of the abdomen showed thickening of the wall of ascending colon near the area of the caecum, and abdominal CT revealed a mass of $3.7 \times 3.6 \times 9.2 \mathrm{~cm}$. A laparotomy was performed, and histological and genetic analyses of the tumor were consistent with the diagnosis of Burkitt lymphoma (cytogenetics: $\mathrm{t}(8 ; 14)(\mathrm{q} 24 ; \mathrm{q} 32))$. No dissemination was observed in further examinations (CT of head and thorax, ultrasound of para-aortic and parailiac lymph nodes, bone 
marrow sampling). The patient received chemotherapy according to the A-group of LMB-89 protocol (dexamethasone, prednisone, cyclophosphamide, vincristine, doxorubicin, and intrathecal methotrexate) and did not face any major complications during the treatment.

Six years later, the patient was again sent to further examinations due to weight loss and continuous pain in the right thigh and lower back. MRI revealed a tumor mass in the lumbar vertebra L3, partially filling the spinal canal. The histological and cytogenetic analyses confirmed Ewing sarcoma (cytogenetics: $\mathrm{t}(11 ; 22)(\mathrm{q} 24 ; \mathrm{q} 12))$. Chemotherapy was carried out according to the ISG/SSG III protocol (vincristine, doxorubicin, cyclophosphamide, actinomycin D, ifosfamide, and etoposide) and local irradiation was administered up to $54 \mathrm{~Gy}$. Apart from nutritional problems, the patient withstood treatments well. The MRI of the trunk and the spine and the flow cytometry of the bone marrow aspirate showed no signs of the tumor at the end of the treatment.

The unusual combination of two separate cancers prompted us to perform further genetic analyses. An array-CGH analysis of the blood nucleated cells was performed, showing a $1.4 \mathrm{Mb}$ deletion at chromosome 7q11.23 (Fig. 1), compatible with the Williams syndrome diagnosis. The deletion consists of 27 genes including CLIP2, GTF2IRD1 and GTF2I, and can be categorized as "classical" according to Delgado et al [2]. No other constitutive genetic changes were identified and both parents had normal array-CGH results.

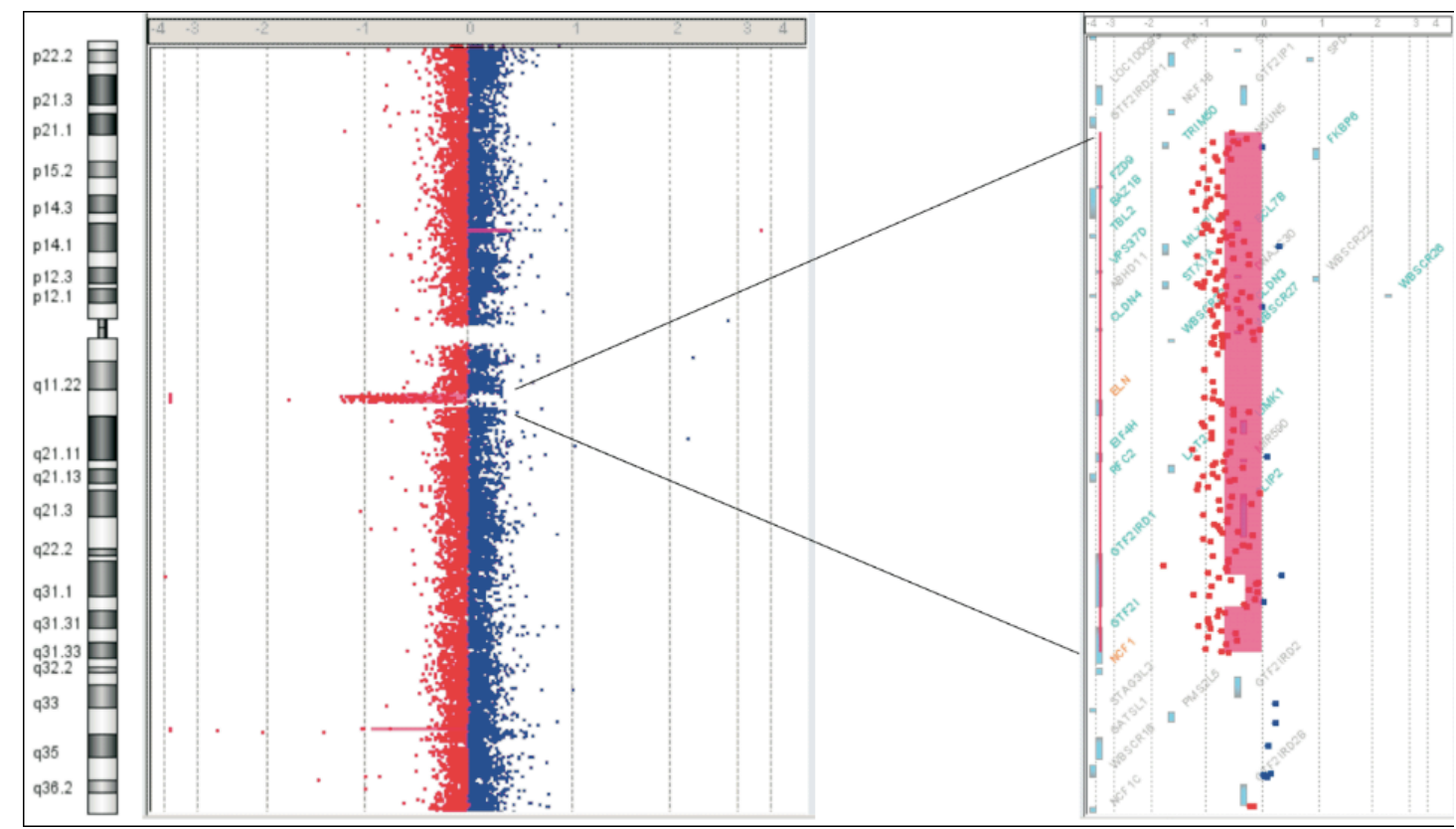

Fig. 1. The array-CGH results are shown in a diagram of chromosome 7. The deletion 7q11.23 is indicated with red hybridization signals, and next to the diagram is an enlargement of the deleted region of size $1.4 \mathrm{Mb}$. 


\section{Discussion}

WS is caused by a deletion of varying length on chromosome 7, leading to an abolition of around 26-28 coding genes with poorly known functions. The deletion in Williams-Beuren syndrome chromosomal region (WBSCR), which occurs sporadically, arises as a consequence of chromosomal misalignment during meiosis due to highly similar low-copy-repeat sequences flanking the region [1]. Exactly how this deletion leads to the characteristic phenotype of WS is unknown.

It has been suggested that 7q11 locus contains potential tumor suppressor genes whose deletion might predispose carriers to hematopoietic malignancies as well as some solid tumors. The presence of only one copy of each gene in WBSCR region can reduce gene expression by half and although this occurs with most of the genes in this locus, there are tissue-specific exceptions, such as GTF2IRD1 (general transcription factor II-I repeat domain- containing protein 1) [1]. Interestingly, several non-deleted genes that flank the region display decreased expression, possibly due to the position effect [1].

Many human malignancies have genetic alterations at chromo- some 7 with the most common finding in the lymphoid, myeloid, and non-epithelial cancers being monosomy 7. Other alterations include trisomy of chromosome 7 and various deletions of the long arm. Deletions at $7 q 11$ has been reported in acute lymphoblastic leukemia, chronic myeloid leukemia and breast carcinoma [3]. Should the microdeletion at 7q11.23 in WS abolish crucial tumor suppressor gene(s), one would expect an increased incidence of malignancies. In a study by Hasle et al. [4], malignancy was not observed in any of the 16 patients with WS in their cohort, thus not suggesting an increased risk of malignancy among WS patients.

Chromosomal translocations are common particularly in hematological malignancies and pediatric sarcomas. Thousands of chromosome translocations have been identified but their etiology is poorly understood. Spatial organization of the chromatin and certain features of DNA sequence, aberrations in DNA-repair pathways and fragile sites all contribute to their genesis [5]. Among malignancies in WS patients (Table I), only cases with Burkitt lymphoma have presented with chromosomal translocations. It is intriguing that our patient had two separate malignancies with a tumor-specific chromosomal translocation in both. As genetic data on tumors accumulates, it is interesting to see if chromosomal translocations are more common in tumors among WS patients.

Secondary malignancies after Burkitt lymphoma are rare. Only a few reports have been published on Ewing sarcoma as a secondary malignancy and, among these, Burkitt lymphoma was the primary cancer in only one case [20]. As a chemotherapy, our patient received doxorubicin and 
cyclophosphamide, and one possibility is that the primary treatment contributed to the occurrence of the Ewing sarcoma.

In summary, we report a unique patient with a constitutional chromosome alteration (WS) and two separate malignant tumors, both carrying aberrant fusion events. Array-CGH did not reveal any additional genetic lesions in our patient. However, our analysis does not rule out the possibility of minor insertions, deletions or mutations not identifiable at the level of array-CGH analysis.

Table 1. Reported tumors in Williams syndrome patients.

\begin{tabular}{|l|l|l|}
\hline Tumor & Age group & Reference \\
\hline Burkitt leukemia & child & 6 \\
\hline Bilateral Burkitt lymphoma (ovaries) & child & 7 \\
\hline Burkitt lymphoma & child & 8 \\
\hline Non-Hodgkin lymphoma & child & 9 \\
\hline Non-Hodgkin lymphoma & child & 10 \\
\hline Non-Hodgkin lymphoma & adult & 11 \\
\hline Pilomyxoid astrocytoma & child & 12 \\
\hline Oligodendroglioma & adult & 13 \\
\hline Oesophageal adenocarcinoma & adult & 14 \\
\hline Fibrous hamartoma & child & 15 \\
\hline Lymphoblastic leukemia & child & 16 \\
\hline Pancreatic adenocarcinoma & adult & 17 \\
\hline Mucinous cystadenoma of ovary & adult & 18 \\
\hline Astrocytoma & child & 19 \\
\hline
\end{tabular}




\section{Conflict of interest}

Nothing to declare.

\section{References}

1. Schubert C. The genomic basis of the Williams-Beuren syndrome. Cell Mol Life Sci 2009;66:1178-1197.

2. Delgado LM, Gutierrez M, Augello B, et al. A 1.3-mb 7q11.23 atypical deletion identified in a cohort of patients with Williams-Beuren syndrome. Mol Syndromol 2013;4:143-147.

3. Zenklusen JC, Conti CJ. Cytogenetic, molecular and functional evidence for novel tumor suppressor genes on the long arm of human chromosome 7. Mol Carcinog 1996;15:167-175.

4. Hasle H, Olsen JH, Hansen J, et al. Occurrence of cancer in a cohort of 183 persons with constitutional chromosome 7 abnormalities. Cancer Genet Cytogenet 1998;105:39-42.

5. Roukos V, Burman B, Misteli T. The cellular etiology of chromosome translocations. Curr Opin Cell Biol 2013;25:357-364.

6. Zhukova N, Naqvi A. Williams-Beuren Syndrome and Burkitt leukemia. J Pediatr Hematol

Oncol 2013;35:30-32.

7. Onimoe GI, Kahwash S, Termuhlen A, et al. Bilateral Burkitt lymphoma of the ovaries: A report of a case in a child with Williams syndrome. Case Rep Med 2011;2011:327263.

8. Thornburg CD, Roulston D, Castle VP. Burkitt lymphoma and Williams syndrome: A model for children with a multisystem disorder and malignancy. J Pediatr Hematol Oncol 2005;27:109-111.

9. Urisarri-Ruiz de Cortazar A, Calvo MG, Donsion MV, et al. Renal dysplasia/hypoplasia, Williams Syndrome phenotype and non-Hodgkin lymphoma in the same patient: Only a coincidence? Pediatr Nephrol 2009;24:1081-1084.

10. Amenta S,MoschoviM, SofocleousC, et al. Non-Hodgkin lymphomain achild with Williams syndrome. Cancer Genet Cytogenet 2004;154:86-88.

11. Felice PV, Ritter SD, Anto J. Occurrence of non-Hodgkin's lymphoma in Williams syndromeCase report. Angiol 1994;45:167-170.

12. Chonan M, Kanamori M, Kumabe T, et al. Pilomyxoid astrocytoma of the cerebellum with Williams syndrome: A case report. Childs Nerv Syst 2013; [Epub ahead of print].

13. Omalu BI, Nnebe-Agumadu UH. Occurrence of anaplastic oligodendroglioma in a patient with Williams syndrome: A case report with analysis of mutational profile of tumor. Niger J Clin Pract 2009;12:200-204.

14. Montano N, De Bonis P, Lauriola L, et al. Late onset cerebellar metastasis from oesophageal adenocarcinoma in Williams Syndrome. J Neurooncol 2008;88:349-351.

15. Togo T, Araki E, Ota M, et al. Fibrous hamartoma of infancy in a patient with Williams syndrome. Br J Dermatol 2007;156:1052-1055.

16. Culic V, Culic S, Armanda V, et al. Single signal of the Williams syndrome chromosome region 1 gene in hyperploidic bone marrow cells of acute lymphoblastic leukemia in a Williams syndrome patient. Med Pediatr Oncol 2002;38:205-207.

17. Flanders TY, Foulkes WD. Pancreatic adenocarcinoma: Epidemiology and genetics. J Med Genet 1996;33:889-898.

18. Marles SL, Goldberg NA, Chudley AE. Mucinous cystadenoma of ovary in a patient with Williams syndrome. Am J Med Genet 1993;46:349.

19. Semmekrot BA, Rotteveel JJ, Bakker-Niezen SH, et al. Occurrence of an astrocytoma in a patient with Williams syndrome. Pediatr Neurosci 1985-1986;12:188-191.

20. Lim SH, Lee JY, Lee JY, et al. Unusual presentation of Ewing sarcoma in the adrenal gland: A secondary malignancy from a survivor of Burkitt lymphoma. Jpn J Clin Oncol 2013;43:676-680. 